\title{
7 COMPOSITION
}

9 Emma L. Moynihan ${ }^{1,2^{*}}$, Karl G. Richards ${ }^{1}$, Fiona P. Brennan ${ }^{1,3}$, Sean F. Tyrrel ${ }^{2}$, Karl Ritz ${ }^{2}$

$11{ }^{1}$ Teagasc, Crops Environment and Land-Use Department, Environmental Research Centre, 12 Johnstown Castle, Wexford, Co. Wexford, Ireland.

$13{ }^{2}$ Cranfield University, School of Applied Sciences, Cranfield, Bedfordshire, MK43 0AL, 14 U.K.

$15{ }^{3}$ Ecological Sciences Group, The James Hutton Institute, Craigiebuckler, Aberdeen, AB15 $168 \mathrm{QH}$, Scotland

18 Running Title: Soil microbial community affects pathogen survival 
24 Teagasc Environmental Research Centre, Johnstown Castle, Wexford. Ireland.

25 emylooo@gmail.com, Phone+353864010364.

26

27

28

29

30

31

32

33

34

35

36

37

38

39

40

41

42

43

44

45

46

48

47 structure associated with soils derived from 12 contrasting land-uses on model

ABSTRACT (200 WORDS)

4 Microbial enteropathogens can enter the environment via landspreading of animal slurries and

5 manures. Biotic interactions with the soil microbial community can contribute to their

6 subsequent decay. This study aimed to determine the impact of microbial community

8 enteropathogen survival. The phenotypic profiles of these soil microbial communities were 
determined by phospholipid fatty acid (PLFA) profiling, and soils were also characterized for a range of physicochemical properties. The persistence of Salmonella Dublin, Listeria monocytogenes, and Escherichia coli was measured over 110 days within soil microcosms. Physicochemical and biotic data were used in stepwise regression analysis to determine the predominant factor related to pathogen-specific death rates. Phenotypic structure, associated with a diverse range of constituent PLFAs, was identified as the most significant factor in pathogen decay for S. Dublin, L. monocytogenes, non-toxigenic E. coli O157 but not for environmentally-persistent $E$. coli. This demonstrates the importance of entire community interactions in pathogen suppression, which are context-specific.

8

9

(1)

\section{INTRODUCTION}

Microbial enteropathogens are released in faecal waste of both animals and humans, and enter the soil environment either directly via faecal shedding, or indirectly via the application of slurry, manure and sewage sludge. In addition, wild animals and birds contribute to enteropathogen load in the environment (Jones, 2001; Jiang et al., 2007; Benskin et al., 2009), and there is evidence to suggest that potentially pathogenic enteric bacteria can exist as naturalised populations within the soil matrix (Texier et al., 2008; Ishii et al., 2006; Brennan et al., 2010). Enteropathogens can pose a serious public health risk, contingent on survivability within the soil environment. Viable pathogens may be transmitted to humans by direct contact with contaminated surfaces and accidental ingestion of faeces or contaminated soil particles (Davis et al., 2005). Pathogens can also be transported via overland or subsurface flow to surface and groundwaters, and infection may arise via ingestion of contaminated water, e.g. Walkerton Outbreak, Ontario in 2000 (Hrudey et al., 2003). It is also 
possible that pathogens could be present on the crop surface following manure application. In this case, a person may become infected if they consume the contaminated produce, as demonstrated by the 2011 E. coli O104 outbreak in Germany, associated with consumption of contaminated beansprouts (Böhmer et al., 2011).

To date, enteropathogen survival in soil has been mostly investigated in relation to prevailing physicochemical conditions. Factors known to affect pathogen survival include moisture, temperature, texture, $\mathrm{pH}$, cation exchange capacity (CEC), UV irradiation, organic matter (OM) and soil nutrient status (summarised by van Elsas et al., 2011). For example, persistence is favoured by cool moist conditions (Cools et al., 2001), where exposure to UV is limited (Hutchison et al., 2004b). Typically, the survival of enteric bacteria is reduced at low $\mathrm{pH}$, and tends to increase when approaching a neutral to alkaline state (Sjogren, 1994). Fine textured soils with well-developed microstructure and high clay content offer habitat, water and nutrients, which can sustain pathogens introduced via manure application (England et al., 1993).

Soil biology also plays an important function in regulating pathogen survival; however research on interactions with the soil community has been comparatively limited. Pertinent biotic interactions include predation (Sørensen et al., 1999), antagonism from indigenous microorganisms (Garbeva et al., 2004) and competition for resources (Irikiin et al., 2006). It has been found that bacteria introduced into soil decline more rapidly when other microbes are present. This decline is apparently accelerated when the indigenous microbial community is increasingly diverse. A range of experimental approaches have been used to manipulate microbial diversity with a view to investigating the relationship between diversity and $E$. coli survivability (Vivant et al, 2013; Yao et al., 2013; Ma et al., 2013; Korajkic et al., 2013; Erickson et al., 2013). All of these studies showed an inverse relationship between community 
complexity and pathogen survival, attributed to progressively increasing competition for resources and antagonistic interactions associated with greater diversity.

The soil microbial community is typically sensitive to changing environmental conditions (Waldrop and Firestone, 2006), and consequent shifts in community structure could influence the survival behaviour of introduced enteric pathogens. Land-use and management has been implicated in shaping the microbial community by modulating the physicochemical environment (Lauber et al., 2008). It has been shown that intensity of landuse (Jangid et al., 2008), length of time under a particular management (Buckley and Schmidt, 2001), substrate addition (Degens et al., 2000) and the presence of a plant rhizosphere (Garbeva et al., 2004) can contribute to defining microbial community structure. Some work has been carried out to demonstrate the effects of land-use and management on pathogen suppression (van Elsas et al., 2002; Williams et al., 2007; Franz et al., 2008; Yao et al., 2013). However, the pathogen survival response is often variable and difficult to predict within a framework of complex interactions between site-specific factors, including current and historical land-use, the physicochemical environment, predominant management strategies and resultant impact on community composition. In addition, these studies focused solely on a single pathogen, namely E. coli O157, despite the fact that survival and behavioural profiles within soil are species, and even strain-specific (Topp et al., 2003). This is because enteropathogens have different physiological properties and life cycles which will influence survivability within the soil matrix (Winfield and Groisman, 2003).

It is therefore unclear whether physicochemical or biotic factors play a dominant role in governing pathogen survival, particularly as few studies have considered both in a coherent manner. Therefore, the aim of this study was to conduct a microcosm study to investigate pathogen survival in relation to naturally-contrasting community phenotypes derived from different land-uses. We hypothesised that soil biology, specifically the phenotypic microbial 
community structure, would be more significant in regulating pathogen decay than soil physicochemical composition. We prescribed the phenotype as the operationally important entity in this context, as it represents the literal manifestation of the microbial community which the introduced bacteria would have encountered.

\section{MATERIALS AND METHODS}

\subsection{Soil collection and initial screening}

Thirty-nine sites across Ireland were initially prescribed based on contrasting land-use, soil type and management regime. Sites consisted of a single uniform field, free of livestock, which was divided into 3 sections. Approximately 20 cores were taken from the top $15 \mathrm{~cm}$ of soil (A horizon) across the $\mathrm{W}$ transect from each section, and were combined to yield a composite sample. Soils from these sites were then homogenised and sieved to $4 \mathrm{~mm}$. Subsamples of approximately 5-10 g freeze-dried soil were weighed out and analysed for community composition by PLFA, as described by Frostegård et al. (1997). Soils were also tested for $\mathrm{pH}$ using an automated Aqualyser $\mathrm{pH}$ meter, \% OM (Davies, 1973), and were assessed by hand texturing (DEFRA, 2010). These data were used to select a suite of 12 contrasting soil types for use in a microcosm experiment investigating pathogen death rates. These 12 soils were comprehensively characterised for a range of physicochemical parameters including total exchange capacity (Ross, 1995), pH (McLean, 1982), \% OM (Schulte and Hopkins, 1986), Olsen P (Olsen and Sommers, 1982); extractable ions (Mehlich, 1984); inorganic nitrogen (Dahnke, 1990); total carbon and nitrogen (Nelson and Sommers, 1996) and soil texture (ASTM D422, 2000) using sieved, air-dried soil. Fresh soil was also tested for microbial biomass carbon, according to the method described by Vance et al., 1987. Average PLFA profiles for the initial 39 soils were used in principal components (PC) analysis. First and second PC scores were ordinated to visualise the distribution of soils 
according to community composition, and were labelled according to soil ID, land-use, texture, $\mathrm{pH}$ and \% OM (Supp. Fig. 1a-e, respectively). By comparing these graphs, it was possible to visualise community differences with respect to physicochemical properties and

152 thus prescribe a broad range of naturally-derived contexts to subsequently characterise 153 pathogen survival.

\subsection{Microcosm establishment}

156 The water holding capacity (WHC) for each prescribed soil was determined by the method

157 described in Franz et al. (2011). Moisture content was then adjusted so that soils exhibited

158 similar cohesiveness to achieve standard friability between different soil types, by wetting-up

159 or restricted slow drying on the bench as appropriate. Following adjustment, soil moisture

160 was measured by oven-drying at $105^{\circ} \mathrm{C}$ for 24 hours, and expressed as a percentage of WHC.

161 Microcosms designed to quantify pathogen survival were established by weighing out

162 aliquots of $5 \mathrm{~g}$ soil into sterile $40 \mathrm{ml}$ polypropylene tubes. The tubes were covered with

163 Parafilm to prevent moisture loss during incubation. Caps were then loosely replaced to allow

164 for gas exchange, whilst minimising the risk of contamination. All tubes were stored at $10^{\circ} \mathrm{C}$

165 until inoculated with the pathogen suspension. This temperature was selected as it reflects the

166 average annual topsoil soil $(0-10 \mathrm{~cm})$ temperature in Ireland. Pathogen inoculation was

167 staggered over a 4-week period, with exactly one week between each inoculation. Therefore

168 the precise community configuration to which each pathogen was exposed was determined by

169 undertaking PLFA analysis at the outset of each inoculation, in order to capture any microbial

170 changes associated with storage and physical alteration, including sieving and moisture

171 adjustment.

\subsection{Pathogen inoculation and enumeration}


174 Four model pathogens were selected to investigate community interactions, namely an environmentally-persistent E. coli (Brennan et al., 2013), Salmonella Dublin (NCTC 9676), Listeria monocytogenes (Strain no. 1778) and non-toxigenic lux-marked E. coli O157 (Strain no. 3704), which has been shown to be a representative proxy for the toxigenic O157 strain of clinical importance (Bolton et al., 1999). These model organisms were considered relevant in terms of public health significance, and they also represented contrasting cellular structures and growth strategies (Winfield and Groisman, 2003). Pathogen inoculum cultures were prepared overnight in Luria-Bertani broth at $37^{\circ} \mathrm{C}$, and washed 3 times in 1/4 strength Ringer's solution. Microcosms were individually inoculated with approximately $10^{8}$ cells of each pathogen, which constituted $10^{7}$ cells g ${ }^{-1}$ soil (dry weight). Final soil moisture following inoculation, at which soils were incubated, was then determined as a percentage of WHC. Pathogen inoculation was staggered into pathogenspecific batches involving all twelve soils simultaneously. These batches were inoculated weekly over a 4-week period, for reasons of practicality. For each pathogen batch, a pool of 96 microcosms per soil type were inoculated at three instances selected at random from the whole (remaining) pool after 2 hours (denoted $\mathrm{T}_{0}$ ) and 2, 4, 8, 16, 32, 64 and 110 days

190 (denoted $\mathrm{T}_{2}, \mathrm{~T}_{4}, \mathrm{~T}_{8}, \mathrm{~T}_{16}, \mathrm{~T}_{32}, \mathrm{~T}_{64}, \mathrm{~T}_{110}$ ). Soils continued to be incubated at $10^{\circ} \mathrm{C}$ throughout these experimental periods. Enumeration was carried out by suspending the soil in $10 \mathrm{ml}$ of $1 / 4$ strength Ringer's 193 solution, vortexing briefly and shaking on an end-over-end shaker for 15 minutes. These 194 suspensions were then used to create serial dilutions, which were then spread-plated onto 195 Sorbitol MacConkey, XLD or Oxford agars (Oxoid) for E. coli spp., S. Dublin and L. 196 monocytogenes, respectively. All plates were incubated at $37^{\circ} \mathrm{C}$ for 24 hours, with the 197 exception of L. monocytogenes - these were incubated at $37^{\circ} \mathrm{C}$ for 48 hours. All soils were 198 screened for bacterial targets prior to the experiment, to ensure background levels were 
negligible. L. monocytogenes could not be quantified at $\mathrm{T}_{110}$, due to excessive growth of background microflora on Oxford agar plates. Therefore, survival data for this organism are

201 only presented to $\mathrm{T}_{64}$.

\subsection{Data analysis}

204 Pathogen survival data were collected by counting characteristic colonies. Triplicate counts 205 for each soil treatment were averaged and were plotted as CFU g ${ }^{-1}$ (dry weight). These data 206 were used to fit exponential decay curves and calculate the average death rate for each 207 pathogen within the context of each soil treatment, according to the following equation: $208 \mathrm{y}=\mathrm{a}+\mathrm{b}^{*} e^{-\mathrm{kt}}$, where $\mathrm{y}$ represents the population (CFU g ${ }^{-1}$ soil dry weight) at a given time $\mathrm{t}, \mathrm{a}+\mathrm{b}$ 209 denotes the apparent starting concentration of cells (i.e. intercept with the y-axis), a denotes 210 the asymptote of the final population concentration, and $\mathrm{k}$ denotes the death rate $\left(\mathrm{d}^{-1}\right)$. This

211 function has been used previously to estimate pathogen death rates (Mubiru et al., 2000;

212 Oliver et al., 2006). PLFA profiles were analysed by principal components (PC) analysis, and 213 relative PLFA abundances were ordinated for each soil independently for each batch. PC 214 analysis was also applied to the entire dataset across the four batches, and the relative PLFA 215 abundances were ordinated accordingly. Physicochemical, community and k-values were 216 averaged per soil, and entered into a forward stepwise regression model (Statistica v. 11) to 217 investigate the predominant influential factor regulating pathogen death rates across the 12 218 soil types.

\subsection{Soil community profiling}


The prescribed 12 soils were labelled alphabetically (Table 1) and PLFAs were labelled numerically (Table 2) to aid visualisation during PC analysis. When PLFA profiles were analysed collectively across all four batches, there was a highly significant effect of batch $(\mathrm{P}<0.001)$ and soil $(\mathrm{P}<0.001)$, but no significant interaction between these terms $(\mathrm{P}=0.2-0.5)$ for any of PC1-4, which accounted for $66 \%$ of the variability between soils. Ordination of mean scores for each batch showed significant separation of all four circumstances, with Batch 3 being notably separated by PC1, 2 and 4 (Fig. 1a). Batches 1, 2 and 4 tended to cluster in the ordinations but were nonetheless significantly separated by PCs 1-3 (Fig. 1b). Ordination of PC1 and PC2 for the PLFA profiles associated with each soil independently showed concomitantly wide dispersion, with notable differences between the ordinations in the four batches. Ordination of corresponding PLFA loadings in this case showed that neither PC1 nor PC2 was dominated by particular PLFA types (Fig. 2a-h).

\subsection{Pathogen death rates}

Pathogens declined in an exponential manner in all instances (Fig. 3). There was visual evidence to suggest different survival characteristics between soils in the form of notably different gradients. This was confirmed by differences in pathogen-specific death rates (Table 3). Overall, there was an order of magnitude difference between highest and lowest death rates, observed for E. coli Isolate 3 in Soil A and L. monocytogenes in Soil C, respectively. The exponential decay function was a significant fit $(\mathrm{P}<0.05)$ for all pathogens within each soil.

There was no association between death rate and PC score for PC1, with the exception E. coli $\mathrm{O} 157$ which showed a significant linear relationship (Fig. 4a, $\mathrm{P}<0.01$ ). A similar relationship was observed between death rate and $\mathrm{PC} 2$ for $S$. Dublin (Fig. 4b, $\mathrm{P}<0.005$ ) and $L$. monocytogenes (Fig. 4c, $\mathrm{P}<0.001$ ) where higher death rates were associated with greater 
positive values in PC2. There was no association between death rate and PC2 for either E. coli

249 Isolate 3 or E. coli O157. There was no association between death rate and PC3 or PC4 for 250 any model pathogen tested.

Stepwise regression showed that variation in death rates between land-use treatments was explained solely and significantly by phenotypic community structure according to PC

253 scores for all model pathogens, with the exception of $E$. coli Isolate 3 (Table 4). No other 254 physicochemical or biotic factor contributed to the stepwise regression model fitting 255 procedure.

\section{DISCUSSION}

258 A broad range of 39 soils were screened to prescribe biologically and physicochemically 259 contrasting soils for subsequent pathogen survival analysis. It was expected that soils from 260 different land-uses would provide the range of properties fit for purpose to test our 261 hypothesis, and this was investigated using a principal-component based screening approach.

262 It was shown that the soils possessed different physicochemical and community compositions, 263 such that an appropriate suite of 12 soils which showed a broad range of similarity and difference across a range of biotic and physicochemical characteristics were selected, relating to the main factors hypothesised to influence pathogen death rates.

\subsection{Soil community profiling}

268 Pathogens were inoculated into these 12 soils on a weekly basis in a series of pathogenspecific batches. PC analysis of average PLFA profiles showed significant differences in community composition between batches (Fig. 1). This indicates community composition

271 within soils was not entirely conserved during the inoculation period. This effectively means

272 that the respective pathogens were inoculated into subtly (but significantly) different 
community contexts. Soil community shifts over storage time has been previously reported

274 (Petersen and Klug, 1994; Wu et al., 2009). However, the primary focus of this study was to

275 create different biological scenarios in order to compare the relative importance of biotic

276 versus physicochemical factors in regulating pathogen survival. Therefore these community

277 shifts did not impact on addressing the central hypothesis.

PC analysis also showed highly significant differences in community phenotypic composition between soils, as anticipated (Fig. 1). Dispersal of soils within the PC trait space indicates that a wide variety of community contexts were included in this study. The lack of a significant soil-by-batch interaction is evidence that the relative differences between

282 communities were conserved over time when all batches were considered together, thus 283 providing evidence that communities were broadly congruent between batches, and allowing similarities in pathogen behaviour to be tentatively evaluated.

The PC plots associated with each batch, representative of the range of soil communities present at respective pathogen-specific $\mathrm{T}_{0}$ 's (Fig. 1) depict the precise community contexts to which the pathogens were exposed. PC analysis revealed significant 288 differences between soil communities within each batch. The PLFA loadings associated with these PCs showed that differences in a range of PLFAs contributed to the significant discrimination between communities associated with these 12 soils (Fig. 1). Therefore, discrimination between communities associated with different land-uses was based on shifts 292 in the total microbial cohort in this case. This contrasts with other work that has looked at the 293 effect of different treatments on community configurations in soil. For example, Bossio et al. 294 (1998) found associations between fatty acid signatures and organic, low input and conventional management, suggesting that particular groups were responsible for variation 296 between management regimes. Similarly Frostegård et al. (1997) showed distinct differences 297 in PLFAs associated with manure and those associated with soil, when investigating the 
impact of manure hotspots on microbial community dynamics. The lack of dominant PLFAs in this case may be due to comparison of a variety of soil communities, encompassing many different land-use treatments and soil types.

\subsection{Pathogen death rates}

303 Death rates in the range of soils differed between pathogens (Fig. 3, Table 3). Greatest initial 304 decay was observed for both E. coli strains compared to L. monocytogenes and Salmonella 305 Dublin. Pathogen survival in soil is associated with initial inoculum density, cell physiology, 306 adaptability to new environments and capacity to utilise available substrate (van Veen et al., 307 1997). These factors may have contributed to differential survival patterns across the suite of

308 pathogens used in this study. Fig. 3 also shows differences in overall persistence. Recovery of 309 E. coli Isolate 3 was highest at the end of the experimental period, which may have been 310 associated with its documented ability to persist and survive long-term within the soil matrix

311 (Brennan et al., 2010; Brennan et al., 2013). L. monocytogenes extraction at $\mathrm{T}_{110}$ was 312 unsuccessful, but a comparison of cell concentration at $\mathrm{T}_{64}$ shows that L. monocytogenes was 313 also strongly competitive across the range of soil treatments and persisted well. This is consistent with previous findings that L. monocytogenes is a highly adaptable, saprophytic organism which is ubiquitous in the soil environment (Weis and Seeliger, 1975; Freitag et al., 316 2009).

Different pathogen death rates were also manifest within each soil. Death rate tended

318 to be greatest within grassland land-use class, and poorest in arable and wood land-use classes 319 for all pathogens. Regression analysis showed that PC scores representative of community 320 composition provided the best predictor of pathogen survival for 3 of 4 pathogens 321 investigated (Fig. 4, $\mathrm{P}<0.01$ ). There was no significant correlation between survival and any 
of the other physicochemical or biological factors tested - such terms were clearly excluded 323 from the regression procedure (Table 4). G, were more suppressive toward the pathogens than those associated with soils from arable or wood land-use classes. PLFA loadings show that the suppressive effect observed in this case was of general rather than specialist nature, caused by interactions with the total microbial consortium within these soils, rather than with specific microbial groups.

Differential survival between grassland and arable soils has been shown previously in the context of the plant pathogen Rhizoctonia solani AG3. Greater microbial diversity in grassland as compared to arable soils, resulted in an enhanced suppressive effect and reduced spread of pathogenic fungal hyphae (van Elsas et al., 2002). It is possible that grassland represents intermediate disturbance levels, as compared to higher disturbance associated with arable and lower disturbance associated with woodland soils. Intermediate disturbance tends to promote diversification of the microbial community (Jangid et al., 2008), which could 336 potentially account for greater suppression witnessed in grassland here. This diversification 337 may have been more pronounced for Soil G, as this soil was particularly antagonistic towards 338 the introduced pathogens. This suggests that the pathogen risk is higher when applying 339 organic materials to arable soils relative to grasslands, as these soils may lack suppressive 340 capacity associated with higher microbial diversity that tends to be promoted by intermediate 341 disturbance regimes.

342 It was shown that pathogen survival was predominantly affected by the soil microbial 343 community. Other work has found circumstantial evidence that antagonistic interactions with 344 the soil community can regulate pathogen decline. For example, Jiang et al. (2002) compared 345 survival of E. coli $\mathrm{O} 157$ in manure-amended autoclaved soil and unautoclaved soil, and noted 346 rapid inactivation in unautoclaved soil. This response was attributed to the soil microbiota and 
was contingent on other factors including temperature and manure:soil ratio. Similarly,

348 Salmonella enterica serovar Newport showed greater initial population increase, slower rate

349 of decline and longer survival periods in manure-amended sterile as compared to non-sterile

350 soil. Again, this response was partially attributed to microbial antagonism (You et al., 2006).

351 Further, work by Franz et al. (2008) investigated the main biotic and physicochemical factors

352 influencing the persistence of E. coli $\mathrm{O} 157$ in a suite of manure-amended soils. They showed

353 that in the presence of manure, pathogen survival was highly correlated with levels of

354 dissolved organic carbon. In organic soils, a secondary correlation was identified with

355 microbial diversity described by molecular techniques. These results suggested that pathogen

356 survival times were mostly contingent on nutrient supply, and could be reduced by amending

357 soil with high quality manure containing a comparatively lower and more complex nutrient

358 load, in order to minimise nutrient availability to opportunistic pathogens. However, the soils

359 that were used in our experiment did not receive any nutrient addition during the incubation

360 period. Potentially, the role of soil biology in pathogen suppression becomes more apparent in

361 the absence of nutrient input. Other work has shown that the competitive ability of $E$. coli

362 O157, characterised by the quantity and rate of resource utilisation, was reduced in the

363 presence of species-rich communities (van Elsas et al., 2012). More recently, Erickson et al.

364 (2014) showed that physicochemical factors including moisture, texture, $\mathrm{pH}$ and electrical

365 conductivity, affected E. coli and Salmonella differently, depending on levels of microbial

366 diversity. Again, this provides further evidence for the important role played by soil

367 microorganisms in regulating pathogen survival.

A recent study by Wang et al. (2014) showed that land-use factors including soil $\mathrm{pH}$,

369 organic matter and sand content significantly influenced the decay of E. coli O157; however

370 the authors did not take account of the inherent soil biology associated with each land-use

371 type. In contrast, we observed that none of the physico-chemical factors included in this study 
could explain differences in pathogen survival between soils, when PC scores representing the

community context were included in regression analysis (Table 4). The survival of all

pathogens except $E$. coli Isolate 3 was significantly correlated with contrasting and unrelated communities associated with natural soils. Therefore these results support the hypothesis that soil biology, specifically microbial community structure, is more important than prevailing physicochemical conditions in regulating pathogen survival.

\subsection{Differential response of $E$. coli Isolate 3}

E. coli Isolate 3 did not respond to the community context in this experiment. This may be due to the fact that it is an environmentally-persistent isolate, which has been shown to form naturalised populations and persist in soil for more than 9 years (Brennan et al., 2010).

Further, E. coli Isolate 3 has been shown to be metabolically flexible, and direct its proteome towards relatively fast growth, under low temperature conditions, thus demonstrating its environmental adaptability (Brennan et al., 2012). Other studies have also reported long-term growth and survival of E. coli in soil (Byappanahalli and Fujioka, 2004; Ishii et al., 2010).

Therefore, E. coli Isolate 3 may not have been as susceptible to community interactions as other organisms used in this study. Alternatively, the lack of correlation for E. coli Isolate 3 could also be linked to the fact that the community context to which this organism was exposed differed to that of other pathogens, due to differential development in absolute community composition during the incubation period.

\section{CONCLUSIONS AND FUTURE RESEARCH}

This work has provided evidence to show that soil biology, specifically the phenotypic community context, determines pathogen survival behaviour and hence we accept our hypothesis. The phenotype is arguably the most relevant construct in this context since it 
represents an integrated description of the literal manifestation of the microbial community

398 which the introduced pathogens encountered. That a wide range of PLFAs appear to be 399 implicated in these relationships suggests that the modulation of the pathogens operates at a 400 scale well beyond one or two community members. However, as different microbial species 401 can contain the same fatty acid signature, the phenotype does not provide information at 402 species level. Thus it cannot be used to derive diversity indices, or draw conclusions on 403 species evenness and abundance (Frostegård et al., 2010). Therefore, nucleic acid-based 404 methods such as DGGE and terminal restriction length fragment polymorphism (T-RFLP), 405 which offer more taxonomic resolution, may have added an extra dimension to this study 406 (Zhang and $\mathrm{Xu}, 2008$ ). For instance, genetic information could have been used to identify 407 microorganisms within phenotypes associated with pathogen suppression. Linking phenotype 408 with genotype and sequencing approaches on the viable community may offer a promising 409 avenue for further research. The precise nature of such survival may be associated with pathogen type. This 411 suggests that the response of different organisms should be taken into account. This study 412 used four model pathogens to illustrate the principles of soil biota affecting survival; however 413 only single strains of Listeria and Salmonella were included and it is likely that inter-strain 414 variability might also occur, which should be taken into account in subsequent studies. 415 Future work should focus on investigating survival characteristics following nutrient 416 addition, as pathogens are typically introduced to soil in an organic carrier material such as 417 manure or sewage sludge. Research should also seek to identify specific microbial 418 configurations that are antagonistic towards human pathogens in soil, and to investigate 419 means of managing the soil in such a way as to allow configurations appropriate to pathogen 420 attenuation to be established. This would encourage more rapid death rates in soil, which 
421 would reduce the risk of pathogen loss to water and crops, and thus break the cycle of

422 infection, leading to better animal and public health protection.

423

424 ACKNOWLEDGEMENTS

425 The authors gratefully acknowledge Teagasc for the funding provided through the Walsh

426 Fellowship Scheme and the Teagasc Post-Doctoral Fellowship Scheme. The authors also wish

427 to thank Prof. Graeme Paton (Aberdeen University, UK) Dr. Des Walsh (Teagasc, Ashtown)

428 and Martina O'Brien (Teagasc, Moorepark) for provision of E. coli, Salmonella and Listeria

429 strains, respectively, and Dr Jim Grant for assistance with the statistical analysis.

430

\section{REFERENCES}

432 ASTM Standard D422-63, 2007. Standard test method for particle-size analysis of soils.

433 ASTM International, West Conshohocken, PA, 2007.

434

435 Benskin, C.M.H., Wilson, K., Jones, K., Hartley, I.R., 2009. Bacterial pathogens in wild 436 birds: A review of the frequency and effects of infection. Biol. Rev. 84, 349-373.

438 Böhmer M.M., Remschmidt C., Wilking H., Deleré Y., an der Heiden M., Adlhoch C., 439 Dreesman J., Ehlers J., Ethelberg S., Faber M., Frank C., Fricke G., Greiner M., Höhle M., 440 Ivarsson S., Jark U., Kirchner M., Koch J., Krause G., Luber P., Rosner B., Stark K., Kühne 441 M., 2011. German outbreak of Escherichia coli O104:H4 associated with sprouts. New 442 England Journal of Medicine 365, 1763-1770.

443 
Bolton, D.J., Byrne, C.M., Sheridan, J.J., McDowell, D.A., Blair, I.S., 1999. The survival characteristics of a non-toxigenic strain of Escherichia coli O157:H7. J. Appl. Microbiol. 86, 407-411.

Bossio, D.A., Scow, K.M., Gunapala, N., Graham, K.J., 1998. Determinants of soil microbial communities: Effects of agricultural management, season, and soil type on phospholipid fatty acid profiles. Microb. Ecol. 36, 1-12.

Brennan, F.P., O'Flaherty, V., Kramers, G., Grant, J., Richards, K.G., 2010. Long-term persistence and leaching of Escherichia coli in temperate maritime soils. Appl. Environ.

454 Microbiol. 76, 1449-1455.

455

Brennan, F.P., Grant, J., Botting, C.H., O’Flaherty, V., Richards, K.G., Abram, F., 2013. Insights into the low-temperature adaptation and nutritional flexibility of a soil-persistent Escherichia coli. FEMS Microbiol. Ecol. 84, 75-85.

459

Buckley, D., Schmidt, T., 2001. The structure of microbial communities in soil and the lasting impact of cultivation. Microb. Ecol. 42, 11-21.

Byappanahalli, M., Fujioka, R., 2004. Indigenous soil bacteria and low moisture may limit but 464 allow faecal bacteria to multiply and become a minor population in tropical soils. Wat. Sci. Tech. 50, 27-32

467 Cabanes, D., Dehoux, P., Dussurget, O., Frangeul, L., Cossart, P., 2002. Surface proteins and 468 the pathogenic potential of Listeria monocytogenes. Trends Microbiol. 10, 238-245. 
470 Cools D., Merckx R., Vlassak K., Verhaegen J., 2001. Survival of E. coli and Enterococcus 471 spp. derived from pig slurry in soils of different texture. Appl. Soil Ecol. 17, 53-62.

Dahnke, W.C., 1990. Testing soils for available nitrogen, in: Westerman (Ed.), Soil Testing and Plant Analysis, Soil Science Society of America Book Series 3. ASA, Madison WI, pp. 120-140.

Davies, B.E., 1973. Loss-on-ignition as an estimate of soil organic matter. Soil Sci. Soc. Am. J. 38, 150-151.

480

Davis M.A., Cloud-Hansen K.A., Carpenter J., Hovde C.J., 2005. Escherichia coli O157:H7

DEFRA, 2010. Fertiliser recommendations for Agricultural and Horticultural Crops (RB209), $8^{\text {th }}$ Ed., The Stationary Office, London, pp. 220.

487

Degens, B.P., Schipper, L.A., Sparling, G.P., Vojvodic-Vukovic, M., 2000. Decreases in organic $\mathrm{C}$ reserves in soils can reduce the catabolic diversity of soil microbial communities. Soil Biol. Biochem. 32, 189-196.

492 England L.S., Lee H., Trevors J.T., 1993. Bacterial survival in soil: Effect of clays and 493 protozoa. Soil Biol. Biochem. 25, 525-531. 
495 Erickson, M.C., Habteselassie, M.Y., Liao, J., Webb, C.C., Mantripragada, V., Davey, L.E., 496 Doyle, M.P., 2014. Examination of factors for use as potential predictors of human enteric 497 pathogen survival in soil. J. Appl. Microbiol. 116(2), 335-349.

498

499 Franz, E., Semenov, A.V., Termorshuizen, A.J., De Vos, O.J., Bokhorst, J.G., van Bruggen 500 A.H.C., 2008. Manure-amended soil characteristics affecting the survival of E. coli $\mathrm{O} 157: \mathrm{H} 7$ 501 in 36 Dutch soils. Environ. Microbiol. 10, 313-327.

502

503 Franz, E., van Hoek, A.H.A.M., Bouw, E., Aarts, H.J.M., 2011. E. coli O157 strain variability 504 in manure-amended soil survival in relation to strain origin, virulence profile and carbon 505 nutrition profile. Appl. Environ. Microbiol. 77, 8088-8096.

506

507 Freitag, N.E., Port, G.C., Miner, M.D., 2009. Listeria monocytogenes - from saprophyte to 508 intracellular pathogen. Nature Rev. Microbiol. 7, 623-628.

509

510 Frostegård, A., Petersen, S.O., Baath, E., Nielsen, T.H., 1997. Dynamics of a microbial 511 community associated with manure hot spots as revealed by phospholipid fatty acid analyses.

512 Appl. Environ. Microbiol. 63, 2224-2231.

513

514 Frostegård Å., Tunlid A., Bååth E., 2010. Use and misuse of PLFA measurements in soils. 515 Soil Biol. Biochem. 43, 1621-1625. 
Garbeva, P., van Veen J.A., van Elsas, J.D., 2004. Microbial diversity in soil: Selection of microbial populations by plant and soil type and implications for disease suppressiveness. Annu. Rev. Phytopathol. 42, 243-270.

Hrudey S.E., Payment P., Huck P.M., Gillham R.W., Hrudey E.J., 2003. A fatal waterborne disease epidemic in Walkerton, Ontario: Comparison with other waterborne outbreaks in the developed world. Water Sci. Technol. 47, 7-14.

Hutchison M.L., Walters L.D., Moore A., Crookes K.M., Avery S.M., 2004b. Effect of length of time before incorporation on survival of pathogenic bacteria present in livestock wastes applied to agricultural soil. Appl. Environ. Microbiol. 70, 75111-5118. soil microbial diversity and survival of E. coli O157:H7. J Environ Sci Health, Part B: Pestic., Food Contam. Agric. Wastes 45, 416-426.

Irikiin, Y., Nishiyama, M., Otsuka, S., Senoo, K., 2006. Rhizobacterial community-level, sole carbon source utilization pattern affects the delay in the bacterial wilt of tomato grown in rhizobacterial community model system. Appl. Soil Ecol. 34, 27-32.

Ishii, S., Ksoll, W.B., Hicks, R.E., Sadowsky, M.J., 2006. Presence and growth of naturalised $72,612-621$. 
541 Jangid, K., Williams, M.A., Franzluebbers, A.J., 2008. Relative impacts of land-use,

542 management intensity and fertilization upon soil microbial community structure in

543 agricultural systems. Soil Biol. Biochem. 40, 2843-2853.

544

545 Jiang, X., Morgan, J., Doyle, M.P., 2002. Fate of Escherichia coli O157:H7 in manure-

546 amended soil. Appl. Environ. Microbiol. 68, 2605-2609.

547

548 Jiang, S., Chu, W., Olson, B., He, J.W., Choi, S., Zhang, J., Le, J., Gedalanga, P., 2007.

549 Microbial source tracking in a small southern California urban watershed indicates wild

550 animals and growth as the source of fecal bacteria. Appl. Microbiol. Biotechnol. 76, 927-934.

551

552 Jones, K., 2001. Campylobacters in water, sewage and the environment. J. Appl. Microbiol.

$55390,68 \mathrm{~S}-79 \mathrm{~S}$.

554

555 Korajkic, A., Wanjugi, P., Harwood, V.J., 2013. Indigenous microbiota and habitat influence

556 Escherichia coli survival more than sunlight in simulated aquatic environments. Appl.

557 Environ, Microbiol. 79(17): 5329. DOI: 10.1128/AEM.01362-13.

558

559 Lauber, C.L., Strickland, M.S., Bradford, M.A., Fierer, N., 2008. The influence of soil

560 properties on the structure of bacterial and fungal communities across land-use types. Soil

561 Biol. Biochem. 40, 2407-2415.

562

563 Ma, J., Ibekwe, M., Yang, C.H., 2013. Influence of bacterial communities based on 454-

564 pyrosequencing on the survival of Escherichia coli O157:H7 in soils. FEMS Microbiol Ecol.

565 DOI: 10.1111/1574-6941.12083. 
567 Matos, A., Kerkhof, L., Garland, J.L., 2005. Effects of microbial community diversity on the 568 survival of Pseudomonas aeruginosa in the wheat rhizosphere. Microb. Ecol. 49, 257-264.

McLean, E.O., 1982. Soil pH and lime requirement, in: Page et al. (Eds.), Methods of Soil

Analysis, Part 2. Agronomy Monographs 9, 2nd edn. ASA and SSSA, Madison, WI, pp. 199223.

Mehlich, A., 1984. Mehlich-3 soil test extractant: A modification of Mehlich-2 extractant.

575 Commun. Soil Sci. Plan. 15, 1409-1416.

576

577 Moynihan, E., Richards, K., Ritz, K., Tyrrel, S., Brennan, F., 2013. The impact of soil type, 578 biology and temperature on the survival of non-toxigenic E. coli O157. Biol. Environ. 113B, $579 \quad 1-6$.

Mubiru, D.N., Coyne, M.S., Grove, J.H., 2000. Mortality of Escherichia coli O157:H7 in two soils with different physical and chemical properties. J. Environ. Qual. 29, 1821-1825.

584 Nelson, D.W., Sommers, L.E., 1996. Total carbon, organic carbon and organic matter, in:

585 Bartels et al. (Eds.), Methods of Soil Analysis: Part 3 Chemical methods, 3rd edn. ASA and 586 SSSA Book Series 5, Madison, WI, pp. 961-1010.

588 Oliver, D.M., Haygarth, P.M., Clegg, C.D., Heathwaite, A.L., 2006. Differential E. coli die589 off patterns associated with agricultural matrices. Environ. Sci. Technol. 40, 5710-5716. 
591 Olsen, S.R., Sommers, L.E., 1982. Phosphorus, in : Page et al. (Eds.), Methods of Soil

592 Analysis, Part 2. Agronomy Monographs 9, 2nd edn. ASA and SSSA, Madison, WI, pp. 403593430.

594

595 Pagliai, M., Vignozzi, N., Pellegrini, S., 2004. Soil structure and the effects of management 596 practices. Soil Till. Res. 79, 131-143.

597

598 Petersen, S.O., Klug, M.J., 1994. Effects of sieving, storage, and incubation temperature on 599 the phospholipid fatty acid profile of a soil microbial community. Appl. Environ. Microbiol. $60060,2421-2430$.

601

602

Rattray, E.A., Prosser, J.I., Killham, K., Glover, L.A., 1990. Luminescence-based

603 nonextractive technique for in situ detection of Escherichia coli in soil. Appl. Environ.

604 Microbiol. 56, 3368-3374.

605

606 Ross, D., 1995. Recommended soil tests for determining exchange capacity, in: Sims, J.T., 607 Wolf, A. (Eds.), Recommended soil testing procedures for the northeastern United States. 608 Northeastern Regional Bulletin No. 493. Agricultural Experimental Station, University of 609 Delaware, Newark, DE, pp. 62-69.

610

611 Schulte, E.E., Hopkins, B.G., 1996. Estimation of soil organic matter by weight loss-on-

612 ignition, in: Magdoff, F.R., Tabatabi, M.A., Hanlon, E.A (Eds.), Soil Organic Matter:

613 Analysis and Interpretation. Special Publication No. 46. ASA and SSSA, Madison, WI, pp. $614 \quad 21-32$. 
616 Sjogren R.E., 1994. Prolonged survival of an environmental Escherchia coli in laboratory soil

617 microcosms. Water, Soil and Air Poll. 75, 389-403.

618

619 Sørensen, S.J., Schyberg, T., Rønn, R., 1999. Predation by protozoa on Escherichia coli K12 620 in soil and transfer of resistance plasmid RP4 to indigenous bacteria in soil. Appl. Soil Ecol.

$621 \quad 11,79-90$.

622

623 Texier, S., Prigent-Combaret, C., Gourdon, M.H., Poirier, M.A., Faivre, P., Dorioz, J.M., 624 Poulenard, J., Jocteur-Monrozier, L., Moënne-Loccoz, Y., Trevisan, D., 2008. Persistence of 625 culturable Escherichia coli fecal contaminants in dairy alpine grassland soils. J. Environ. 626 Qual. 37, 2299-2310.

627

628 Topp, E., Welsh, M., Tien, Y.C., Dang, A., Lazarovits, G., Conn, K., Zhu, H., 2003. Strain629 dependent variability in growth and survival of Escherichia coli in agricultural soil. FEMS 630 Microbiol. Ecol. 44, 303-308.

631

632 Vance, E.D., Brookes, P.C., Jenkinson, D.S., 1987. An extraction method for measuring soil 633 microbial biomass C. Soil Biol. Biochem. 19, 703-707.

634

635 van Elsas, J.D., Garbeva, P., Salles, J., 2002. Effects of agronomical measures on the 636 microbial diversity of soils as related to the suppression of soil-borne plant pathogens.

637 Biodegradation 13, 29-40.

638 
van Elsas, J.D., Hill, P., Chronakova, A., Grekova, M., Topalova, Y., Elhottova, D.,

640

641 Kristufek, V., 2007. Survival of genetically marked Escherichia coli O157:H7 in soil as

642

643

644

van Elsas, J.D., Semenov, A.V., Costa, R., Trevors, J.T., 2011. Survival of Escherichia coli in the environment: fundamental and public health aspects. ISME J. 5, 173-183.

645

646

649

650

651

652

653

654

655

656

657

658

659

660 Weis, J., Seeglier, H.P.R., 1975. Incidence of Listeria monocytogenes in nature. Appl. 661 Microbiol. 30, 29-32.

662

van Elsas, J.D., Chiurazzi, M., Mallon, C.A., Elhottovā, D., Krištůfek, V., Salles, J.F., 2012.

Microbial diversity determines the invasion of soil by a bacterial pathogen. P. Natl. Acad. Sci. USA 109, 1159-1164.

Vivant, A., Garmyn, D., Maron, P., Nowak, V., Piveteau., 2013. Microbial diversity and structure are drivers of the biological barrier against Listeria monocytogenes in soil. PLoS ONE 8(10): e76991.

Waldrop, M.P., Firestone, M.K., 2006. Seasonal dynamics of microbial community composition and function in oak canopy and open grassland soils. Microb. Ecol. 52, 470-479.

Wang, H., Zhang, T., Wei, G., Wu, L., Wu, J., Xu, J., 2014. Survival of Escherichia coli O157: H7 in soils under different land-use types. Environ. Sci. Poll. Res. 21, 518-524. 
663

664

665

666

667

668

669

670

671 672 Geoderma 150, 171-178.

673

674

675

676

677

678 You, Y., Rankin, S.C., Aceto, H.W., Benson, C.E., Toth, J.D., Dou, Z., 2006. Survival of

679

680

681

682 Zhang L., Xu Z., 2008. Assessing bacterial diversity in soil. J. Soil Sed. 8, 379-388.

Williams, A.P., Avery, L.M., Killham, K., Jones, D.L., 2007. Survival of Escherichia coli

O157:H7 in the rhizosphere of maize grown in waste-amended soil. J. Appl. Microbiol. 102, 319-326.

Winfield, M.D., Groisman, E.A., 2003. Role of nonhost environments in the lifestyles of Salmonella and Escherichia coli. Appl. Environ. Microbiol. 69, 3687-3694.

Wu, Y., Ding, N., Wang, G., Xu, J., Wu, J., Brookes, P.C., 2009. Effects of different soil weights, storage times and extraction methods on soil phospholipid fatty acid analyses.

Yao, Z., Wei, G., Wang, H., Wu, L., Wu, J., Xu, J. Survival of Escherichia coli O157:H7 in soils from vegetable field under different cultivation patterns. Appl. Environ. Microbiol. 2013; DOI: 10.1128/AEM.03605-12.

Salmonella enterica serovar Newport in manure and manure-amended soils. Appl. Environ. Microbiol. 72, 5777-5783.

683

684

685 
687 Table 1: Physicochemical and biomass properties of the 12 soils utilised for pathogen survival analysis experiments

\begin{tabular}{|c|c|c|c|c|c|c|c|c|c|c|c|c|c|c|c|c|}
\hline $\begin{array}{l}\text { Soil } \\
\text { ID* }\end{array}$ & $\begin{array}{l}\text { Site } \\
\text { coordinates }\end{array}$ & $\begin{array}{l}\text { Land use } \\
\text { category }\end{array}$ & $\begin{array}{l}\text { Specific } \\
\text { land use }\end{array}$ & $\begin{array}{l}\text { Total CEC } \\
\left(\text { ME } 100 \mathrm{~g}^{-1}\right)\end{array}$ & $\mathrm{pH}$ & $\begin{array}{l}\% \\
\text { Organic } \\
\text { matter }\end{array}$ & $\begin{array}{l}\text { Olsen } \\
\text { P } \\
\text { (ppm) }\end{array}$ & $\begin{array}{l}\% \\
\text { Organic } \\
\mathrm{C}\end{array}$ & $\% \mathrm{C}$ & $\% \mathbf{N}$ & $\begin{array}{l}\text { C:N } \\
\text { ratio }\end{array}$ & $\begin{array}{l}\% \\
\text { Clay }\end{array}$ & $\begin{array}{l}\% \\
\text { Silt }\end{array}$ & $\begin{array}{l}\% \\
\text { Sand }\end{array}$ & $\begin{array}{l}\text { Moisture } \\
(\% \text { field } \\
\text { capacity) })^{\star *}\end{array}$ & $\begin{array}{l}\text { Biomass C } \\
\text { ( } \mu \mathrm{g} \mathrm{C} \mathrm{g-1} \\
\text { dry soil) }\end{array}$ \\
\hline A & $52.17 \mathrm{~N}, 6.31 \mathrm{~W}$ & grass & grazing & 11.7 & 6.2 & 6.1 & 46.7 & 3.3 & 3.75 & 0.36 & 10.42 & 13.6 & 34.1 & 52.3 & 46.3 & 356 \\
\hline B & $52.17 \mathrm{~N}, 6.31 \mathrm{~W}$ & grass & grazing & 13.2 & 5.6 & 6.4 & 54.7 & 3.6 & 3.80 & 0.36 & 10.56 & 12.9 & 31.6 & 55.5 & 48.3 & 384 \\
\hline C & $52.52 \mathrm{~N}, 6.55 \mathrm{~W}$ & wood & forestry & 26.4 & 7.5 & 5.2 & 8.0 & 4.1 & 4.55 & 0.25 & 17.97 & 25.2 & 33.0 & 41.8 & 41.1 & 230 \\
\hline $\mathrm{D}$ & $52.51 \mathrm{~N}, 6.54 \mathrm{~W}$ & wood & willow & 17.8 & 7.6 & 5.4 & 94.7 & 3.5 & 3.79 & 0.31 & 12.09 & 21.0 & 22.0 & 57.0 & 38.8 & 263 \\
\hline$E$ & $52.21 \mathrm{~N}, 7.19 \mathrm{~W}$ & arable & maize & 10.0 & 6.4 & 3.0 & 70.3 & 1.5 & 1.89 & 0.21 & 8.84 & 19.4 & 32.6 & 48.1 & 43.0 & 81 \\
\hline $\mathrm{F}$ & $52.21 \mathrm{~N}, 7.18 \mathrm{~W}$ & arable & cabbage & 10.0 & 7.0 & 3.8 & 47.0 & 2.0 & 2.47 & 0.22 & 11.04 & 21.9 & 35.9 & 42.1 & 44.3 & 113 \\
\hline G & $52.10 \mathrm{~N}, 8.14 \mathrm{~W}$ & grass & grazing & 14.8 & 5.5 & 7.2 & 138.0 & 3.9 & 5.78 & 0.44 & 13.24 & 16.5 & 32.3 & 51.2 & 41.7 & 381 \\
\hline $\mathrm{H}$ & $52.21 \mathrm{~N}, 7.18 \mathrm{~W}$ & grass & grazing & 11.8 & 5.7 & 6.8 & 54.7 & 3.9 & 4.17 & 0.41 & 10.17 & 19.3 & 45.8 & 43.9 & 45.0 & 485 \\
\hline I & $52.30 \mathrm{~N}, 8.12 \mathrm{~W}$ & grass & $\begin{array}{l}\text { grazing } \\
\text { till, mustard }\end{array}$ & 22.0 & 6.4 & 13.8 & 240.0 & 5.9 & 7.60 & 0.77 & 9.83 & 23.5 & 41.4 & 35.1 & 54.5 & 695 \\
\hline $\mathrm{J}$ & $52.51 \mathrm{~N}, 6.55 \mathrm{~W}$ & arable & cover & 13.3 & 6.9 & 4.2 & 178.7 & 3.0 & 3.04 & 0.27 & 11.26 & 10.7 & 22.4 & 66.9 & 35.6 & 122 \\
\hline K & $52.21 \mathrm{~N}, 7.19 \mathrm{~W}$ & grass & grazing & 12.9 & 5.9 & 7.8 & 86.7 & 4.0 & 4.55 & 0.48 & 9.55 & 20.3 & 36.2 & 43.6 & 44.7 & 415 \\
\hline $\mathrm{L}$ & $52.51 \mathrm{~N}, 6.55 \mathrm{~W}$ & arable & till, sprayed & 12.9 & 6.9 & 4.2 & 145.0 & 2.8 & 2.84 & 0.28 & 10.27 & 8.8 & 21.7 & 69.5 & 36.0 & 115 \\
\hline
\end{tabular}

*c.f. Figs. 2, 3, 4 and Supp. Fig. 1

**Moisture content at which samples were

incubated 
694 Table 2: PLFA I.D and corresponding biomarkers (c.f. Fig. 2 and Supp. Fig. 1)

\begin{tabular}{ll|ll}
\hline $\begin{array}{l}\text { PLFA } \\
\text { ID }\end{array}$ & \multicolumn{1}{l}{$\begin{array}{l}\text { Biomarker } \\
\text { ID }\end{array}$} & $\begin{array}{l}\text { PLFA } \\
\text { Biomarker }\end{array}$ \\
\hline 1 & $12: 0$ & 20 & $17: 0 \mathrm{br}$ \\
2 & $14: 0$ & 21 & $17: 1 \mathrm{w} 8 \mathrm{c}$ \\
3 & i15:0 & 22 & cy17:0 \\
4 & a15:0 & 23 & $17: 1 \mathrm{w} 8 \mathrm{t}$ \\
5 & $15: 0$ & 24 & $17: 1 \mathrm{w} 7$ \\
6 & $2-\mathrm{OH} 14: 0$ & 25 & $17: 0$ \\
7 & i16:1 & 26 & $12 \mathrm{Me})$ \\
8 & $16: 1 \mathrm{w} 11 \mathrm{c} 6,9$ \\
9 & $3-\mathrm{OH} 14: 0$ & 27 & $18: 1 \mathrm{w} 9 \mathrm{c}$ \\
10 & i16:0 & 28 & $18: 1 \mathrm{w} 7 \mathrm{t}$ \\
11 & $16: 1 \mathrm{w} 11 \mathrm{t}$ & 30 & $18: 1 \mathrm{w} 13$ \\
12 & $16: 1 \mathrm{w} 7 \mathrm{c} 10 / 11$ \\
13 & $16: 1 \mathrm{w} 7 \mathrm{t}$ & 31 & $18: 0$ \\
14 & $16: 1 \mathrm{w} 5$ & 32 & $18: 0$ \\
15 & $16: 0$ & 33 & $(10 \mathrm{Me})$ \\
16 & Me17:0 & $35: 0 \mathrm{cy}$ \\
17 & isomer & & $19: 0$ \\
18 & isomer2 & 36 & $20: 4$ \\
19 & i17:0 & 37 & $20: 5 \mathrm{w} 3$ \\
\hline & & & \\
\hline
\end{tabular}

695

696

697 Table 3: Death rates of pathogens introduced into soils from different land-uses $(n=3)$

\begin{tabular}{l|llll}
\hline \multicolumn{5}{c}{ K-values (days $\left.^{-1}\right)^{*}$} \\
Soil & S. Dublin & L. monocytogenes & E. coli LYS 9 & E. coli O157 \\
ID & $0.22 \pm 0.02$ & $0.13 \pm 0.03$ & $0.89 \pm 0.29$ & $0.13 \pm 0.05$ \\
A & $0.10 \pm 0.03$ & $0.07 \pm 0.02$ & $0.11 \pm 0.02$ & $0.09 \pm 0.03$ \\
B & $0.09 \pm 0.01$ & $0.07 \pm 0.02$ & $0.42 \pm 0.11$ & $0.09 \pm 0.03$ \\
C & $0.12 \pm 0.01$ & $0.07 \pm 0.02$ & $0.08 \pm 0.01$ & $0.09 \pm 0.03$ \\
D & $0.12 \pm 0.03$ & $0.10 \pm 0.02$ & $0.17 \pm 0.04$ & $0.17 \pm 0.03$ \\
E & $0.13 \pm 0.03$ & $0.12 \pm 0.02$ & $0.55 \pm 0.11$ & $0.09 \pm 0.03$ \\
F & $0.24 \pm 0.05$ & $0.40 \pm 0.08$ & $0.59 \pm 0.12$ & $0.51 \pm 0.07$ \\
G & $0.25 \pm 0.03$ & $0.22 \pm 0.05$ & $0.71 \pm 0.15$ & $0.22 \pm 0.06$ \\
H & $0.13 \pm 0.04$ & $0.10 \pm 0.02$ & $0.28 \pm 0.05$ & $0.14 \pm 0.03$ \\
I & $0.13 \pm 0.01$ & $0.10 \pm 0.01$ & $0.19 \pm 0.04$ & $0.13 \pm 0.04$ \\
J & $0.23 \pm 0.03$ & $0.21 \pm 0.06$ & $0.30 \pm 0.05$ & $0.16 \pm 0.02$ \\
K & $0.13 \pm 0.02$ & $0.14 \pm 0.01$ & $0.22 \pm 0.04$ & $0.24 \pm 0.06$ \\
L & & & & \\
\hline
\end{tabular}

*Exponential decay model significantly fit curves for all pathogens and treatments $(\mathrm{P}<0.05)$ 
701 Table 4: Stepwise multiple regression results involving prediction of pathogen death rates

702 versus physico-chemical and biological parameters (see text)

\begin{tabular}{|c|c|c|c|c|c|c|c|c|c|}
\hline & $\begin{array}{l}\text { Adjusted } \\
\mathrm{r}^{2}\end{array}$ & SS & df & $\begin{array}{l}\text { MS } \\
\text { model }\end{array}$ & $\begin{array}{l}\text { SS } \\
\text { model }\end{array}$ & $\begin{array}{l}\text { df } \\
\text { residual }\end{array}$ & $\begin{array}{l}\text { MS } \\
\text { residual }\end{array}$ & $\mathbf{F}$ & $\mathbf{p}$ \\
\hline E. coli 0157 PC1 & 0.455 & 0.077 & 1 & 0.077 & 0.076 & 10 & 0.008 & 10.2 & 0.010 \\
\hline S. Dublin PC2 & 0.519 & 0.023 & 1 & 0.023 & 0.018 & 10 & 0.002 & 12.9 & 0.005 \\
\hline L. monocytogenes PC2 & 0.667 & 0.066 & 1 & 0.066 & 0.028 & 10 & 0.003 & 23.1 & 0.001 \\
\hline E. coli Isolate 3 & No fit & & & & & & & & \\
\hline
\end{tabular}

704

705

706

707

708

709

710

711

712

713

714

715

716

717

718

719

720

721

722 
724 Figure 1: Ordinations of (a) first and second principal and (b) third and fourth PCs derived 725 from average PLFA profiles in soils according to the pathogen batch with which they were 726 inoculated (points show means \pm standard error $(n=36)$.

727

728 Figure 2: Ordination of soils according to first and second PCs derived from individual PLFA profiles and corresponding loadings plots for each pathogen batch at respective $\mathrm{T}_{0}$ 's for soils inoculated with (a, b) S. Dublin, (c, d) L. monocytogenes, (e, f) E. coli Isolate 3 and (g, h) E. coli O157. Data represent PC scores \pm standard error $(n=3)$. Soil identification codes are in Table 1.

733

Figure 3: Decay curves for (a) S. Dublin, (b) L. monocytogenes, (c) E. coli Isolate 3 and (d) E. coli $\mathrm{O} 157$ following inoculation to soil microcosms. Data represent average $\log _{10} \mathrm{CFU} \mathrm{g}^{-1}$ soil (dry weight $) \pm$ standard error $(n=3)$. Soil abbreviation codes are as in Table 1.

Figure 4: Relationship between death rates of (a) E. coli O157, (b) S. Dublin and (c) $L$. monocytogenes and community structure represented by PC scores derived from average PLFA profiles associated with each batch. Data represent average values \pm standard error $(\mathrm{n}=3)$. See Table 1 for soil identification. 


\section{SUPPLEMENTARY INFORMATION}

749 Supplementary Figure 1: First and second PCs derived from PLFA profiles of 39 soils

750 according to (a) soil ID - letter codes A-L relate to final 12 soils selected for pathogen

751 survival analysis, alphanumeric codes relate to other soils profiled, (b) land-use, (c) texture,

752 (d) $\mathrm{pH}$ and (e) \% OM (n=3). Encircled data-points represent final 12 soils selected for

753 pathogen survival analysis in all graph panels.

754

755

756

757

758

759

760

761 


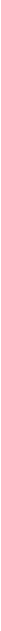



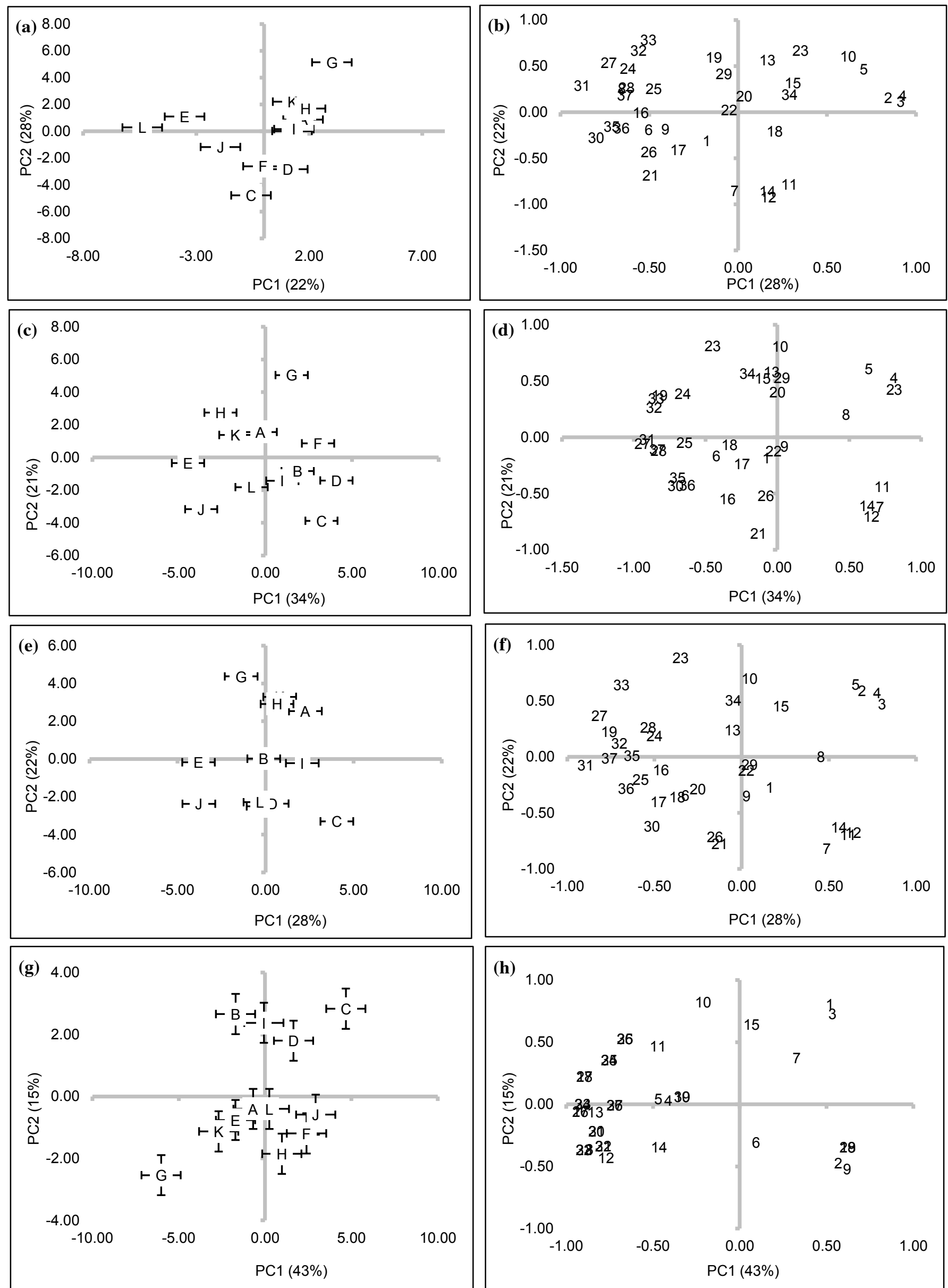


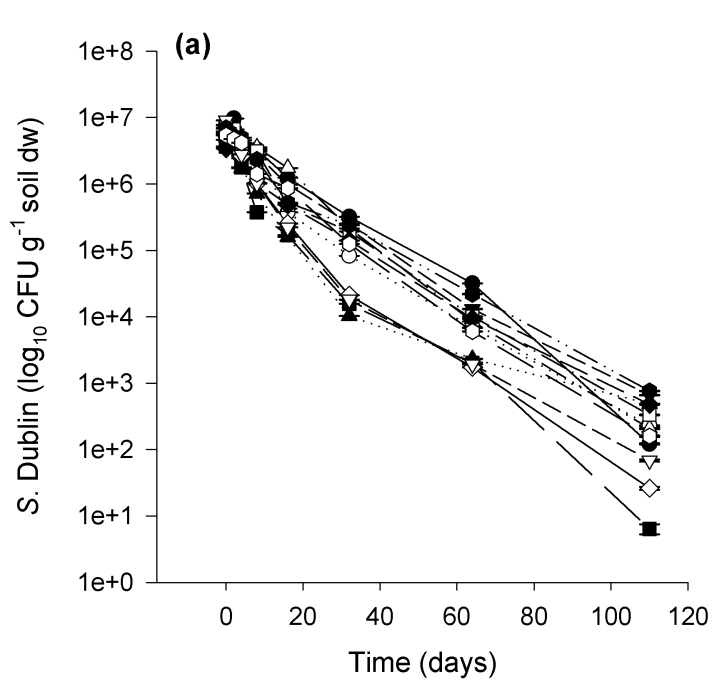

(b)
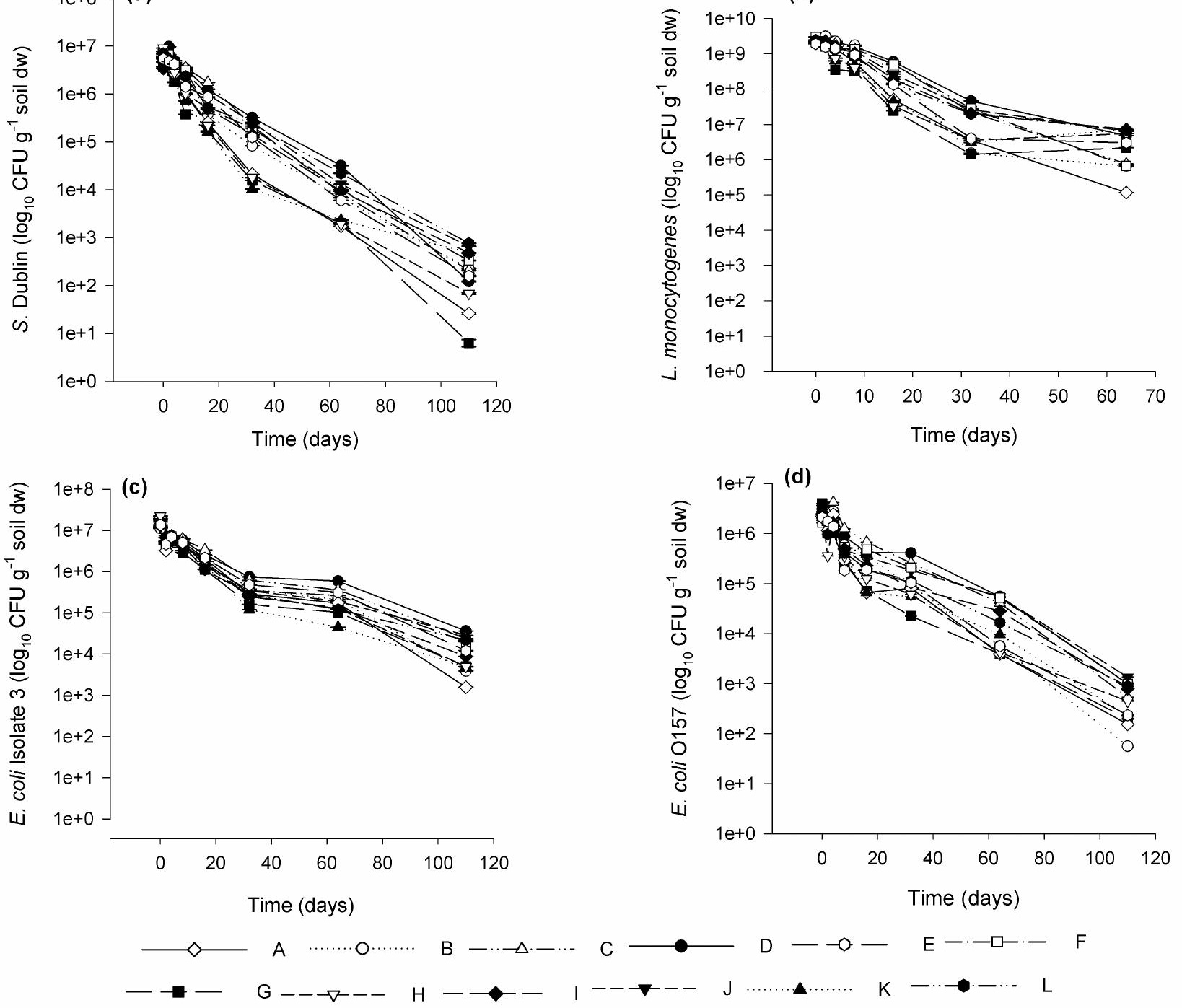


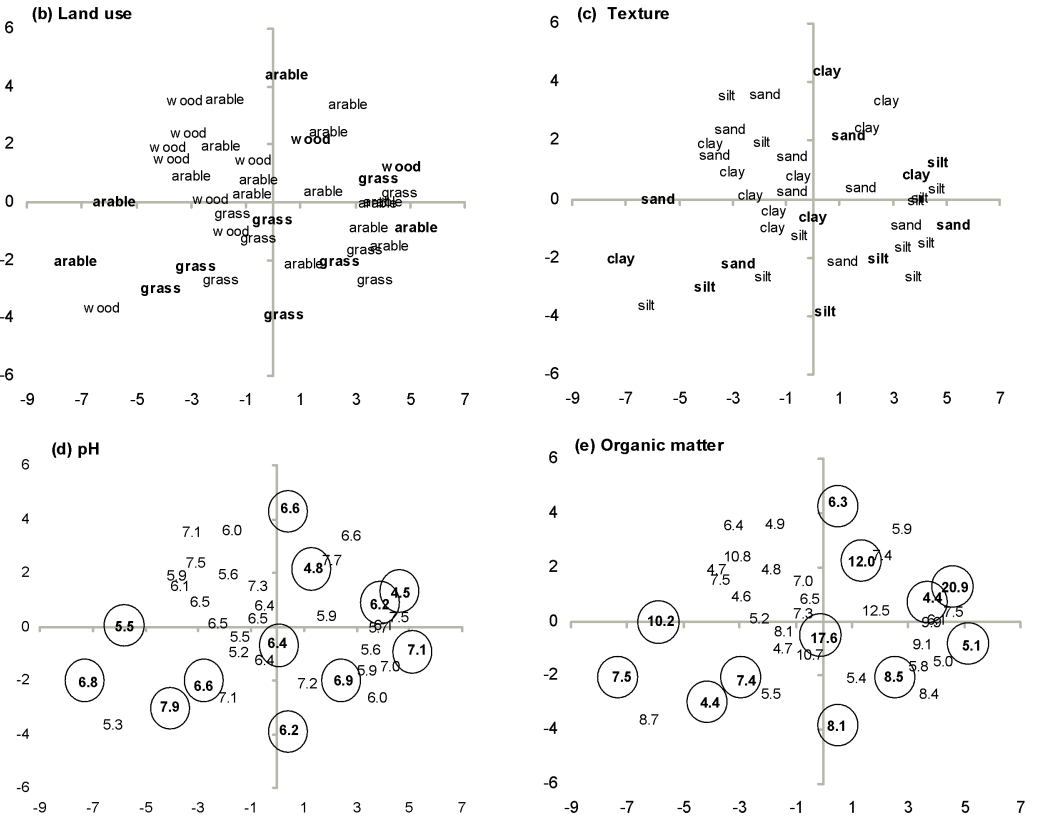

